\title{
A CLINICAL REVIEW OF UTERINE LIPOLEIOMYOMA: A STUDY FOR VALUE AND LIMITATIONS OF RADIOLOGIC EVALUATION IN PREOPERATIVE DIAGNOSIS OF LIPOLEIOMYOMA
}

\author{
Sun Joo Lee, MD, Hee Dong Chae, MD, Ba Da Jeong, MD, Su Kyoung Kwon, MD, Sung Hoon Kim, MD, \\ Chung Hoon Kim, MD, Byung Moon Kang, MD \\ Department of Obstetrics and Gynecology, Asan Medical Center, University of Ulsan College of Medicine, Seoul, Korea
}

\section{Objective}

The present analysis was performed to confirm clinical characteristics of lipoleiomyoma, and to understand the usefulness and limitations of radiologic evaluation in preoperative diagnosis. Finally, the objective of the study is to provide reliable information to establish a treatment plan.

Methods

A retrospective review was conducted on 51 patients, who had lipoleiomyoma as pathologic diagnosis after operation at Asan Medical Center from 1995 to 2009. Clinical characteristics were obtained by review of medical record. Radiologic findings and pathologic data were also obtained.

\section{Results}

The patient's ages ranged from 29 to 82 years, with a mean of $52.1 \pm 10.8$ years. The mean tumor size was $5.6 \pm 3.5 \mathrm{~cm}$ (range, $1-15 \mathrm{~cm})$. Forty six patients (90\%) had their tumors in the uterine corpus, and 3 patients $(6 \%)$ had their tumors in the broad ligament. One in the cervix and one retroperitoneal tumor beneath posterior cul-de-sac were indentified. All patients underwent ultrasound, computed tomography (CT) or magnetic resonance imaging (MRI). Before surgery, 7 patients (14\%) were diagnosed with lipoleiomyoma and 8 patients $(16 \%)$ were diagnosed with ovarian tumors. No tumor was reported to have any cytological atypia, necrosis or other degenerative changes. There were no recurrence or fatalities related to tumor.

\section{Conclusion}

Lipoleiomyoma is a rare, benign, uterine neoplasm that requires no treatment when asymptomatic. The fatty nature of the tumor is valuable in preoperative diagnosis with CT and MRI. But the extrauterine lipoleiomyoma including broad ligament can especially resemble ovarian teratoma. Pathological examination of the surgically excised tumor confirmed the diagnosis.

Keywords: Lipoleiomyoma; Uterine leiomyoma; Ultrasonography; Computed tomography; Magnetic resonance imaging

지방평활근종(lipoleiomyoma)은 지방세포(adipocyte) 및 평활근세포 (smooth muscle cell)로 구성되어 있다. 모든 자궁근종(leiomyoma)에 서 $0.35 \%-2.1 \%$ 의 빈도로 보고되는 매우 드문 종양이다[1,2]. 지방평 활근종의 발생 원인은 아직 명확하지 않다. 임상경과는 자궁근종과 유 사한 것으로 알려져 있지만 1990년 Scurry와 Hack [3]는 지방평활근 종에서 생겨난 지방평활근육종(lipoleiomyosarcoma)을 보고하기도 하 였다[4]. 치료는 자궁근종과 비슷하여 증상이 있는 경우 수술적 치료 를 하지만 증상이 없으면 추적관찰 한다. 컴퓨터단층촬영(computed tomography)이나 자기공명영상(magnetic resonance imaging) 등으로 수술 전에 진단된 경우도 있었다[5]. 지방평활근종은 잘 분화된 지방육
Received: 2012.5.30. Revised: 2012.7.22. Accepted: 2012.8.16. Corresponding author: Hee Dong Chae, MD

Department of Obstetrics and Gynecology, Asan Medical Center, University of Ulsan College of Medicine, 88 Olympic-ro 43-gil, Songpa-gu, Seoul 138-736, Korea

Tel: +82-2-3010-3649 Fax: +82-2-476-7331

E-mail: hdchae@amc.seoul.kr

This is an Open Access article distributed under the terms of the Creative Commons Attribution Non-Commercial License (http://creativecommons.org/licenses/ by-nc/3.0/) which permits unrestricted non-commercial use, distribution, and reproduction in any medium, provided the original work is properly cited.

Copyright $\odot$ 2012. Korean Society of Obstetrics and Gynecology 
종 및 난소의 기형종과 유사하여 감별하기 어렵다.

지방평활근종에 대한 연구는 특히 아시아에서 소규모로 제한되어 있 거나 진단 후 추적관찰에 대한 내용이 부족한 실정이다. 따라서 본 연 구는 본원에서 진단된 51 예의 지방평활근종을 분석하여 자연 경과를 명확하게 확인하고 영상학적 검사의 유용성과 한계를 이해함으로써 지 방평활근종의 치료 방침을 세우는 데 도움을 주고자 시행하였다.

\section{연구대상 및 방법}

본 연구는 1995년부터 2009년까지 서울아산병원 산부인과에서 수술 후 지방평활근종으로 진단받은 환자 51 명을 대상으로 의무기 록을 후향적으로 검토하였다. 지방평활근종이 자궁넓은인대(broad ligament)에 위치했던 3명과 뒤쪽 더글라스와(posterior cul-de-sac)의 배막뒤공간(retroperitoneum)에서 진단된 1명도 같이 조사하였다.

모든 환자는 수술 전에 환자 문진 및 내진을 포함한 이학적 검사를 시행하였으며 초음파, 컴퓨터단층촬영 또는 자기공명영상 중 최소 하 나 이상의 영상학적 검사를 시행하였다. 수술 당시 나이, 체질량 지수 그리고 수술 전 주된 증상과 수술 적응증 등의 임상적 소견을 조사하 였으며 수술 소견과 병리학적 소견을 바탕으로 수술방법, 지방평활근 종의 크기와 개수, 수술 중 위치, 수술 후 동반 진단된 질환을 조사하였 다. 이후 추적관찰 기간 동안의 재발 및 지방평활근종으로 인한 사망 및 합병증을 조사하였다. 본 연구에서 지방평활근종의 재발은 이 후 영 상학적 검사나 수술로 지방평활근종을 진단받은 경우로 정의하였다.

\section{결 과}

환자의 평균나이는 52. $1 \pm 10.8$ 세였으며 평균 체질량지수는 $25.4 \pm 3.4$ $\mathrm{kg} / \mathrm{m}^{2}$ 이었다(Table 1). 환자군의 연령 분포는 29세에서 82세까지이고, 51세에서 60세까지 환자가 22명(43\%)으로 가장 많았다(Table 2).

수술 전에 증상이 없었던 환자가 33 명(65\%)이었고 수술을 받게 된 주 증상은 폐경여성에서 질 출혈 7 명 $(14 \%)$, 골반통증 6 명(12\%), 월경 과다 3 명 $(6 \%)$, 허리통증 2 명 $(4 \%)$ 이었다. 무증상 환자는 자궁근종을 진 단받고 추적관찰하던 중 근종 크기가 증가한 경우나 검진 등으로 우연 히 발견된 난소 종양 등을 이유로 수술하고 지방평활근종을 진단받았 다(Table 3). 수술을 받게 된 적응증을 살펴보면 자궁근종을 의심하고 수술을 한 경우가 32 명 $(63 \%)$, 난소종양을 의심하고 수술한 경우가 8 명 (16\%)이었고 지방평활근종을 진단받고 수술한 경우는 7명(14\%)이었 다. 그 외 2 명(4\%)은 자궁탈출, 1 명(2\%) 자궁내막암, 그리고 1명(2\%)은 자궁목상피내종양을 이유로 수술적 치료를 시행하였다.

지방평활근종을 절제하거나 자궁을 단순 절제하는 수술을 시행하였 고 25명(49\%)은 복강경수술, 23 명(45\%)은 개복술, 2 명(4\%)은 질식수 술, 나머지 1 명(2\%)은 자궁경수술을 시행받았다.

수술 소견에서 46 명(90\%)은 자궁 체부, 3 명(6\%)은 자궁넓은인대에
Table 1. Patients characteristics $(n=51)$

\begin{tabular}{|lc|}
\hline Variables & Mean \pm standard deviation (range) \\
\hline Ages $(\mathrm{yr})$ & $52.1 \pm 10.8(29-82)$ \\
Height $(\mathrm{cm})$ & $155.5 \pm 5.5(1.46-1.68)$ \\
Weight $(\mathrm{kg})$ & $61.6 \pm 9.6(44-94)$ \\
Body mass index $\left(\mathrm{kg} / \mathrm{m}^{2}\right)$ & $25.4 \pm 3.4(18.5-33.7)$ \\
\hline
\end{tabular}

Table 2. Age distribution $(n=51)$

\begin{tabular}{|lc|}
\hline Ages of operation & No. $(\%)$ \\
\hline$\leq 40$ & $7(14)$ \\
$41-50$ & $13(25)$ \\
$51-60$ & $22(43)$ \\
$61-70$ & $6(12)$ \\
$71-80$ & $2(4)$ \\
$>80$ & $1(2)$ \\
\hline
\end{tabular}

Table 3. Symptoms

\begin{tabular}{|lc|}
\hline Presenting symptoms & No. (\%) \\
\hline No symptoms & $33(65)$ \\
Vaginal bleeding in postmenopausal women & $7(14)$ \\
Pelvic pain & $6(12)$ \\
Menorrhagia & $3(6)$ \\
Back pain & $2(4)$ \\
\hline
\end{tabular}

Table 4. Site distribution $(n=51)$

\begin{tabular}{|lc|}
\hline Site & No. (\%) \\
\hline Uterine corpus & $46(90)$ \\
Broad ligament & $3(6)$ \\
Cervix & $1(2)$ \\
Retroperitoneum & $1(2)$ \\
\hline
\end{tabular}

지방평활근종이 있었다. 1 명(2\%)은 자궁경부에서 다른 1명(2\%)은 뒤 쪽 더글라스와의 배막뒤공간에서 진단되었다(Table 4).

수술소견 및 병리학적 소견상 지방평활근종 크기는 평균 5.6 \pm 3.5 $\mathrm{cm}$ (범위, 1-15 cm)고 5명(10\%)에서는 지방평활근종이 다수로 존재 하였다.

모든 환자는 수술 전에 영상학적 검사를 시행하였는데 37명(72\%)은 오직 초음파만을 시행하였고 12명(24\%)은 초음파와 컴퓨터단층검사 를 시행하였다. 2 명(4\%)은 초음파와 자기공명영상을 시행하였다. 영상 학적 소견으로 수술 전에 지방평활근종을 진단받은 환자는 7명(14\%) 이었다. 난소의 종양으로 진단받은 환자는 8 명 $(14 \%)$ 이었고 3 명은 악성 가능성이 있는 난소의 종양으로 진단받았다(Table 5).

병리학적 진단상 지방평활근종과 동반 진단된 질환은 자궁선근증이 13 명 $25 \%$, 자궁근종이 12 명 $(24 \%)$, 자궁내막용종 2 명 $(4 \%)$, 경계성 난 
Table 5. Diagnostic image modality $(n=51)$

\begin{tabular}{|c|c|c|c|c|}
\hline No. $(\%)$ & Ultrasound (51) & & Computed tomography (12) & Magnetic resonance imaging (2) \\
\hline \multirow[t]{3}{*}{$37(72)$} & Uterine myoma & 32 & $(-)$ & $(-)$ \\
\hline & Ovarian tumor & 3 & $(-)$ & $(-)$ \\
\hline & Uterine lipoleiomyoma & 2 & $(-)$ & $(-)$ \\
\hline \multirow[t]{12}{*}{$12(24)$} & Teratoma of ovary & & Teratoma of ovary & $(-)$ \\
\hline & Uterine myoma & & Uterine myoma & $(-)$ \\
\hline & Uterine myoma & & Teratoma of ovary (possible malignancy ) & $(-)$ \\
\hline & Uterine myoma & & Uterine lipoleiomyoma & $(-)$ \\
\hline & Uterine myoma & & Uterine lipoleiomyoma & $(-)$ \\
\hline & Uterine myoma & & Uterine myoma & $(-)$ \\
\hline & Ovary tumor or subserosal myoma & & Subserosal myoma & $(-)$ \\
\hline & Subserosal myoma & & Ovarian tumor (possible malignancy) & $(-)$ \\
\hline & Ovarian tumor & & Teratoma of ovary & $(-)$ \\
\hline & Myoma with 2nd degeneration & & Uterine myoma & $(-)$ \\
\hline & Uterine myoma & & Uterine liopleiomyoma & $(-)$ \\
\hline & Ovarian tumor & & Teratoma of ovary (possible malignancy) & $(-)$ \\
\hline \multirow[t]{2}{*}{$2(4)$} & Uterine myoma & & $(-)$ & Lipoleiomyoma \\
\hline & Ovary tumor or myoma & & $(-)$ & Myoma with 2nd degeneration \\
\hline
\end{tabular}

소종양과 지궁내막암이 각각 1 명 $(2 \%)$ 진단되었으며 병리학적 보고서 상 세포학적 이형성, 괴사 또는 다른 변성은 없었다.

평균 추적관찰 기간은 22.8 개월(범위, $1-110$ 개월)이었다. 추적관찰 기간 동안에 지방평활근종과 관련된 사망은 없었고 재발도 발견되지 않았다.

\section{고 찰}

본 연구는 지방평활근종의 임상경과를 명확하게 하여 치료방침에 도 움이 되고자 시행되었다. 51 예를 분석해 본 결과 지방평활근종은 양성 질환임을 알 수 있었다. 대부분의 지방평활근종은 자궁의 체부에서 발 견되나 자궁경부, 자궁넓은인대, 그리고 배막뒤공간에서도 발생할 수 있다[6-8]. 대부분 폐경기 이후의 여성에게 주로 발생한다. 2006년 Wang 등[1]은 모든 지방평활근종이 단독으로 진단되었다고 발표하였 지만 본 연구에서는 5 명(10\%)에서 지방평활근종이 다수로 존재하였다.

지방평활근종은 조직학적으로 다양한 양의 지방세포, 평활근세포 그 리고 섬유화 조직으로 이루어진다[9]. 지방세포는 종양 전체에 걸쳐 균 등하게 분포할 수도 있고 일부 영역에 집중되어 분포할 수도 있다. 또 한 지방평활근종의 지방구성 요소의 정도는 광범위하게 다를 수 있고 지방구성 요소의 정도는 지방평활근종의 진단을 위해 중요하지 않다. 모든 지방평활근종은 조직학적으로 성숙한 지방세포와 평활근세포로 이루어져 있고 어떠한 유사분열 소견(mitotic activity)도 없고 지방모세 포(lipoblast)도 보이지 않는다. 구성세포의 이형성, 및 괴사도 관찰되지

\section{않는다[1].}

발생에 대한 이론은 정립되어 있지 못하여 여러 가지 이론이 통용되 고 있다. 제기되는 여러 이론 중에 가장 많이 인정받는 이론은 다음 두 이론이다. 하나는 평활근세포의 지방조직 화생(lipomatous metaplasia) 으로 인해 발생한다는 내용이고 다른 하나는 지방세포가 잘못 위치한 배아지방세포 또는 간질성 간엽세포에서 기원한다는 내용이다[10]. 지 방평활근종에서 조직학적으로 지방모세포가 관찰되지 않고 어떠한 괴 사도 발견되지 않아 자궁근종의 근육세포가 지방조직으로 화생한다는 이론이 가장 호소력 있다[1,2].

지방평활근종 환자에서 나타나는 증상은 월경과다, 골반통증 그리고 혹의 크기 증가로 인한 증상이다. 그러나 본 연구에서와 마찬가지로 대 부분의 환자는 증상이 없다[11]. 증상이 없는 경우에는 치료를 필요로 하지 않고, 증상이 있을 경우 수술을 시행하는데 지방평활근종만을 절 제하거나 자궁을 단순 절제한다.

진단은 대부분의 경우 수술 후 병리학적 진단으로 이루어 졌으나 본 연구에서 보여지듯 수술 전 영상학적 검사를 통해서 진단 된 경우도 있 다. 하지만 잘 분화된 지방평활근육종이나 난소의 기형종과 같은 상태 와 많이 닮아 있을 수 있기 때문에 진단이 어려움이 있다. 특징적인 초 음파 검사 소견은 평활근층에 부합되는 저 에코성의 테두리로 부분적 으로 둘러싸인 지방조직에 부합되는 고 에코성인 종괴이다[6]. 컴퓨 터단층촬영에서는 더 특징적인 소견을 나타내어 종양이 자궁 내에 존 재하는 경우 잘 경계지어진 지방성분 종괴가 지방성분이 아닌 연부조 직 안에서 보인다[7,10]. 자기공명영상에서는 T1과 T2 강조영상에서 신호가 증가된 소견으로 보이며, 지방 구성 요소는 지방억제기법(fat- 
suppression techniques)을 사용하여 신호 증가가 없으면 확인할 수 있다[7].

이러한 영상학적 검사의 특성상 종괴가 자궁체부에 존재하는 경우에 는 영상학적 검사로 수술 전에 진단할 수 있다. 그러나 자궁넓은인대와 배막뒤공간과 같이 자궁 밖에 위치하는 경우에는 수술이 필요한 난소 의 종양으로 진단될 수 있다. 이 임상 분석에서도 난소의 종양으로 진 단받은 환자가 8 명 $(16 \%)$ 이였다. 이 중에 5 명(10\%)은 아무런 증상 없이 수술이 필요한 난소의 종양을 우연히 진단받고 수술을 시행한 경우이 었다. 특히 지방성분을 포함하는 비교적 흔한 난소의 기형종과 감별이 어렵다. 난소 기형종의 경우 수술적 치료가 필요하지만, 무증상의 지방 평활근종의 경우 보존적 치료가 가능하기 때문에 이의 감별은 치료 계 획 수립에 중요하다. 또한 지방평활근종의 지방구성 요소의 정도는 광 범위하게 다를 수 있어 지방구성 요소가 적은 경우 종괴가 자궁근층안 에 존재하는 경우에도 수술 전 진단이 용이하지 않을 수 있다.

2008년 Loffroy 등[4]은 증상이 없는 68세 환자가 이학적 검사로 골 반 종괴를 진단받고 초음파, 컴퓨터단층촬영 그리고 자기공명영상을 시행하여 자궁평활근종을 진단받은 예를 발표하였는데 영상학적 소견 상 자궁평활근종이 강력히 의심되었지만 복수가 동반되어 있어 악성 질환을 배제하기 위해서 병리학적 확진이 필요했다. 그러나 환자는 간 경변으로 간 기능이 저하되어 수술을 시행할 수 없어 경피바늘생검을 시행해 지방평활근종을 진단하였다. 무증상의 지방평활근종은 보존적 치료가 가능하지만 이렇게 다른 상태를 완벽하게 배제할 수 없을 땐 병 리학적 확진이 필요하다. 수술이 불가능한 환자에서 경피바늘생검을 통해 지방평활근종을 확진하고 보존적 치료를 시행한 첫 번째 예로 의 미가 있다.

자궁평활근종은 양성질환이나 고체 성분으로 구성되어 있어 위치에 따라 수술이 필요한 난소의 난종 및 악성 질환과 감별이 필요할 때가 있다. 주로 폐경 후 여성에서 발생하기 때문에 난소의 난종과 감별이 필요할 때는 더욱 수술적 치료와 병리학적 진단이 필요하다. 수술이 불 가능한 상태의 환자에서 경피바늘생검은 병리학적 진단을 할 수 있는 유용한 수단이 될 수 있다.

본 연구는 국내에서 비교적 많은 예의 지방평활근종을 검토해서 임 상경과 및 진단 방법을 정리하고자 한 것에 큰 의의가 있다. 51 예를 통 해 지방평활근종은 양성경과를 취한다는 것을 알 수 있었고 악성 질환 과 감별이 필요하거나 난소 종양과의 감별이 필요한 경우에는 초음파 보다는 컴퓨터단층촬영과 자기공명영상이 수술 전 진단에 도움이 될
수 있다고 결론 내릴 수 있다. 만약 난소 종양과 감별이 어려울 때는 증 상이 없는 환자에서라도 수술을 시행하여 반드시 병리학적 진단이 필 요하다고 생각된다.

\section{References}

1. Wang $X$, Kumar D, Seidman JD. Uterine lipoleiomyomas: a clinicopathologic study of 50 cases. Int J Gynecol Pathol 2006;25:239-42.

2. Aung T, Goto M, Nomoto M, Kitajima S, Douchi T, Yoshinaga M, et al. Uterine lipoleiomyoma: a histopathological review of 17 cases. Pathol Int 2004;54:751-8.

3. Scurry J, Hack M. Leiomyosarcoma arising in a lipoleiomyoma. Gynecol Oncol 1990;39:381-3.

4. Loffroy R, Nezzal N, Mejean N, Sagot P, Krausé D. Lipoleiomyoma of the uterus: imaging features. Gynecol Obstet Invest 2008;66:73-5.

5. Ekici E, Vicdan K. Uterine myolipoma: diagnosis by ultrasound. Int J Gynaecol Obstet 1993;42:167-71.

6. Prieto A, Crespo C, Pardo A, Docal I, Calzada J, Alonso P. Uterine lipoleiomyomas: US and CT findings. Abdom Imaging 2000:25:655-7.

7. Aizenstein R, Wilbur AC, Aizenstein S. CT and MRI of uterine lipoleiomyoma. Gynecol Oncol 1991;40:274-6.

8. Sieiński W. Lipomatous neometaplasia of the uterus. Report of 11 cases with discussion of histogenesis and pathogenesis. Int J Gynecol Pathol 1989;8:357-63.

9. Tsushima Y, Kita T, Yamamoto K. Uterine lipoleiomyoma: MRI, CT and ultrasonographic findings. Br J Radiol 1997;70:1068-70.

10. Shintaku M. Lipoleiomyomatous tumors of the uterus: a heterogeneous group? Histopathological study of five cases. Pathol Int 1996;46:498-502.

11. Oppenheimer DA, Carroll BA, Young SW. Lipoleiomyoma of the uterus. J Comput Assist Tomogr 1982;6:640-2. 


\section{지방평활근종의 임상적 분석: 지방평활근종 진단 시 영상학적 검사의 유용성과 한계에 대한 고찰}

\section{울산대학교 의과대학 산부인과학교실}

이선주, 채희동, 정바다, 권수경, 김성훈, 김정훈, 강병문

\section{목적}

지방평활근종은 매우 드문 자궁의 양성 신생물로 이에 대한 연구보고는 소규모로 제한적이었다. 본 논문의 임상적 분석은 자궁평활근종의 임상적 경과를 명확하게 하고 또한 수술 전 진단 시 영상학적 검사의 유용성과 한계를 이해하여 치료계획을 수립하는 데 도움을 주고자 시행하였다.

\section{연구방법}

본 연구는 1995년부터 2009년까지 서울아산병원에서 수술 후 지방평활근종으로 진단된 51예를 후향적으로 검토하였다. 임상적 소견, 영 상학적 소견, 그리고 병리적 소견을 환자 의무기록을 토대로 조사하였다.

\section{결과}

환자의 평균나이는 $52.1 \pm 10.8$ 세였고 종양의 크기의 평균값은 $5.6 \pm 3.5 \mathrm{~cm}$ 였다. 수술 소견에서 46 명(90\%)은 자궁체부, 3 명(6\%)은 자궁 넓은인대에 지방평활근종이 있었다. 1 명(2\%)은 자궁경부에서 다른 1 명(2\%)은 뒤쪽 더글라스와의 배막뒤공간에서 진단되었다. 모든 환자 는 수술 전에 영상학적 검사를 시행하였는데 수술 전에 지방평활근종을 진단받은 환자는 7 명 $(14 \%)$ 이었다. 난소 종양으로 진단받은 환자 가 8 명 $(16 \%)$ 이었다. 병리학적 소견상 세포학적 이형성, 괴사 또는 다른 변성은 없었다. 추적 관찰기간 동안에 지방평활근종과 관련된 사망 은 없었고 재발도 발견되지 않았다.

\section{결론}

지방평활근종은 양성 종양이며 지방성분으로 인한 영상학적 특성은 컴퓨터단층촬영과 자기공명영상으로 지방평활근종을 진단하는 데 유 용하다. 지방평활근종이 자궁넓은인대나 배막뒤공간에 위치하는 경우에는 수술이 필요한 난소종양과 감별하기 어렵다. 결국 이러한 경우 에는 증상이 없어도 병리학적 진단을 위해 수술적 치료를 시행해야 한다.

중심단어: 지방평활근종, 자궁근종, 초음파, 컴퓨터단층촬영, 자기공명영상 